\title{
A NOTE ON THE CALCULATION OF WATER EXCHANGE
}

\author{
By JOHN P. PETERS, DAVID M. KYDD aNd PAUL H. LAVIETES * \\ (From the Department of Internal Medicine of Yale University, New Haven)
}

(Received for publication March 2, 1933)

Newburgh and Johnston (1) have proposed a method for the determination of water balances that depends largely on the demonstrations by Benedict and Root (2) and others that, in the absence of sweating, losses of body weight not referable to the obvious differences between the weights of ingesta on the one hand and the urine and feces on the other hand, parallel closely the heat production of normal subjects and patients with diabetes and thyroid disease. The data of Benedict and Root (2) were secured under basal conditions. Newburgh and Johnston (1) have presented evidence, secured from a small number of selected normal subjects or subjects apparently normal in all respects except body weight, that the relation between heat production and insensible weight loss is maintained not only in the resting postabsorptive state, but also under conditions of feeding and activity, as long as the latter do not provoke sensible perspiration.

Whether the same relation is maintained during abnormal states of hydration or during diseases involving particularly disturbances of the circulation, respiration or intermediary metabolism has not been ascertained with certainty and has been questioned by many observers; although Lashmet (3), from Newburgh's clinic, has proposed the application of the principle to the analysis of the water exchange in cases of nephritis with edema.

It is not the purpose of the present paper to analyze the propriety of the assumptions made by Newburgh and Johnston nor the applicability of their techniques to the solution of problems of water exchange in patients with edema or dehydration. The immediate object is merely to call attention to certain unnecessary complications in their procedures for the calculation of the water exchange which seem to have escaped attention.

The calculation procedures of Newburgh and Johnston (1), which they have set up in the form of balances, introduce no entirely new principles, but merely utilize certain well known chemical and metabolic relations. They can be briefly summarized in the following manner:

$$
\text { 1. Insensible loss }(I L)=\left(W_{1}-W_{2}\right)+\left(w_{f}-w_{e}\right) \text {, }
$$

when $W_{1}, W_{2}$, $w_{f}$ and $w_{e}$ stand respectively for initial and final body weights and weights of intake and excreta.

* Sax Research Fellow in Clinical Medicine. 
2. $1.301(I L)+19.27=$ cals. per hour,

where $I L$ is expressed in grams per hour. This formula has been derived by us from the data of Benedict and Root (2) which have been used by Newburgh and Johnston (1) for their calculations.

$$
\text { 3. Insensible water }(I P)=I L+\mathrm{O}_{2}-\mathrm{CO}_{2} \text {. }
$$

This follows naturally from the fact that the processes of metabolism of the various food stuffs involve the absorption of oxygen and the discharge of $\mathrm{CO}_{2}$, for which the insensible loss must be corrected before it represents water exchange. To estimate the oxygen absorbed and the $\mathrm{CO}_{2}$ discharged it is necessary to know the quantities of each food stuff burned in the metabolic mixture and the relative amounts of $\mathrm{O}_{2}$ and $\mathrm{CO}_{2}$ produced in its combustion. To calculate the metabolic mixture it is reasonably assumed that glycogen stores in the body remain unchanged and that all carbohydrate fed is burned. The protein burned is calculated by multiplying the nitrogen excretion by the usual factor 6.25. Under these circumstances the metabolic mixture becomes

$$
\text { Cals. }=4.1 C+4.1(6.25 N)+9.3 F,
$$

where $C, F$ and $N$ represent, respectively, carbohydrate and fat burned and urinary nitrogen, the last serving as a measure of the protein metabolism.

As cals. has been derived from Equation 2, if the carbohydrate fed and the nitrogen excreted are known, the fat burned may be readily calculated. Comparison of the protein and fat fed with the amounts of the same food components burned permits deduction also of the amounts of fat and protein stored in the body.

The factors for oxygen consumed, and for carbon dioxide and water

\begin{tabular}{|c|c|c|c|}
\hline & $\mathrm{O}_{2}$ & $\mathrm{CO}_{2}$ & $\mathrm{H}_{2} \mathrm{O}$ of oxidation \\
\hline & grams & grams & grams \\
\hline 1 gram protein $P \ldots \ldots \ldots \ldots \ldots \ldots \ldots$ & $\begin{array}{l}1.40 \\
1.14 \\
2.89\end{array}$ & $\begin{array}{l}1.48 \\
1.55 \\
2.81\end{array}$ & $\begin{array}{l}0.41 \\
0.60 \\
1.07\end{array}$ \\
\hline
\end{tabular}
produced, in the combustion of each food stuff are:

4. Water balance $(W B)=\left(\mathrm{H}_{2} \mathrm{O}_{f}-\mathrm{H}_{2} \mathrm{O}_{e}\right)+\left(\mathrm{H}_{2} \mathrm{O}_{\text {ox. }}-I P\right)$.

To the positive terms on the right side of this equation Newburgh and Johnston have added "preformed water," to express water which is held in the body in conjunction with protein, fat, glycogen, etc., and which is presumably released when these substances are burned. The proportions 
of water ascribed to each of these food stuffs on the basis of experimental data and calculations are: for 1 gram of protein 3 grams of water; for 1 gram of glycogen 3 grams of water $;^{1}$ and for 1 gram of fat 0.1 gram of water. An examination of the concept of "preformed water" and the data upon which it is based will be made at another time. It is entirely relevant to the purposes of this paper to point out that this fraction of water belongs in a different category from the other fractions included in the water balance calculations. $\mathrm{H}_{2} \mathrm{O}_{f}-\mathrm{H}_{2} \mathrm{O}_{e}-I P$ represents the exchange of water between the organism and the external environment; $\mathrm{H}_{2} \mathrm{O}_{\text {ox. }}$ represents water formed de novo by the combustion of food stuffs ingested or derived from body tissues. "Preformed water," on the other hand, was water of the body in the beginning and remains so to the end, having the same ponderousness and solvent properties as other water in the body and no more. Any change in the volume of the total body water, which includes this preformed fraction, is included in the initial and final body weight, which are in turn included in $I P$. Equation 4 as it stands expresses change in the volume of water in the body as a whole, while "preformed water," at the most, indicates only a change in the nature and allocation of the water in the body. It seems preferable, therefore, to maintain the distinction at this point and to omit "preformed water" from the equation.

It is evident that the last term of Equation 4 is the right hand side of Equation 3 with the sign changed, and that Equation 3 includes Equation 1. By combination, then, the general Equation 5 may be derived.

$$
\begin{aligned}
& \text { 5. }(W B)=\left(W_{2}-W_{1}\right)+\left(w_{e}-w_{f}\right)+\left(\mathrm{H}_{2} \mathrm{O}_{f}-\mathrm{H}_{2} \mathrm{O}_{e}\right) \\
& +\left(\mathrm{H}_{2} \mathrm{O}_{\text {ox. }}-\mathrm{O}_{2}+\mathrm{CO}_{2}\right) \text {. }
\end{aligned}
$$

It is evident at a glance that $\left(W_{2}-W_{1}\right)$ represents the weight increase or weight balance; $w-\mathrm{H}_{2} \mathrm{O}$, weight - water content of ingesta or excreta, equals solids. By comparing the last term of the equation with the table of values of oxygen used and carbon dioxide and water formed in the combustion of food stuffs it will be seen that $\mathrm{H}_{2} \mathrm{O}_{\text {ox. }}-\mathrm{O}_{2}+\mathrm{CO}_{2}=$ for fat 1.0 , for carbohydrate 1.0 and for protein 0.49 . This follows naturally from the facts that:

$$
\begin{aligned}
1 \text { gram fat }+2.89 \mathrm{O}_{2}=2.81 \mathrm{CO}_{2}+1.07 \mathrm{H}_{2} \mathrm{O}, \\
\text { or } 1 \text { gram } F=1.07-2.89+2.81=1 \text { gram }
\end{aligned}
$$

1 gram carbohydrate $+1.14 \mathrm{O}_{2}=1.55 \mathrm{CO}_{2}+0.6 \mathrm{H}_{2} \mathrm{O}$,

$$
\text { or } 1 \text { gram } C=0.60-1.14+1.55=1 \text { gram }
$$

1 gram protein $+1.40 \mathrm{O}_{2}=1.48 \mathrm{CO}_{2}+0.41 \mathrm{H}_{2} \mathrm{O}$,

or 1 gram $P=0.41-1.40+1.48=0.49$ gram

1 Because of their prior assumption that carbohydrate burned is the same as carbohydrate fed, Newburgh and Johnston make no correction for "preformed water" of glycogen. They do, however, subsequently recognize its existence. 
Fat and carbohydrate, by the addition of oxygen, are converted entirely to carbon dioxide and water. Only a fraction of the protein undergoes a similar fate, the remainder is excreted as urea and other waste products which are accounted for in the excretory solids. Equation 5 may then be written in the form 6 and the tedious calculations of $\mathrm{O}_{2}, \mathrm{CO}_{2}$ and $\mathrm{H}_{2} \mathrm{O}_{\text {ox. }}$. may be omitted.

6. $W B=\left(W_{2}-W_{1}\right)+\left(S_{e}-S_{f}\right)+(C+0.49 P+F)$.

Water balance $=$ weight balance + solids lost + food burned

Why Newburgh and Johnston went to the trouble of the intermediary calculations required for the estimation of oxygen, carbon dioxide and water of oxidation is not clear. They give the impression, whatever may have been their intentions, that the calculation of the "predicted water balance " from "theoretical loss of weight" and of the "determined water balance" are independent of one another and therefore serve as checks upon the accuracy of the method of estimating the nature of fluid and food exchanges: Actually their "predicted water balance" is $(\Delta \mathrm{Wt}$. observed $-\Delta \mathrm{Wt}$. calculated) in which are used the same basic equations and data which are used for the calculation of the " determined water balance."

Equation 6 embodies, in simple terms, that part of Newburgh and Johnston's calculations which refers to changes in the total water content of the body. If it is desired to include "preformed water" an additional term may be added to the right hand side.

7. $P W$ (preformed water) $=$

$$
3\left(P_{b}-P_{f}\right)+0.1\left(F_{b}-F_{f}\right)+3\left(C_{b}-C_{f}\right),
$$

where subscripts $b$ and $f$ represent, respectively, food stuffs burned and fed. If it be assumed, as Newburgh and Johnston have done, that body glycogen remains unchanged, $C_{b}=C_{f}$ and the last term cancels out. The ingested foods are, of course, estimated from dietary tables or by analysis. The foods burned are derived from Equation 2 as described above.

In Newburgh and Johnston's calculations $P W$ is added to the right side of Equation 6. If $P W$, as Gamble and others have implied, represents specifically intracellular water, it may be well to retain the distinction between $W B$ and $P W$. In this case, furthermore, $W B-P W$ should be a measure of the intracellular water exchange.

\section{SUMMARY}

In the procedures of Newburgh and Johnston for the calculation of water balances separate calculations of $\mathrm{CO}_{2}$ and water produced and oxygen consumed in the combustion of food stuffs are unnecessary procedures. The balances of Newburgh and Johnston have been transformed into equations which simplify calculations of the water exchange. 


\section{BIBLIOGRAPHY}

1. Newburgh, L. H., and Johnston, M. W., The Exchange of Energy between Man and the Environment. Charles C. Thomas, Baltimore, 1930.

Newburgh, L. H., Johnston, M. W., and Falcon-Lesses, M., J. Clin. Invest., 1929-30, viii, 161. Measurement of Total Water Exchange.

Newburgh, L. H., and Johnston, M. W., J. Clin. Invest., 1920-30, viii, 197. The Nature of Obesity.

2. Benedict, F. G., and Root, H. F., Arch. Int. Med., 1926, 1xxxviii, 1. Insensible Perspiration: its Relation to Human Physiology and Pathology.

3. Lashmet, F. H., J. Michigan S. M. Soc., 1932, xxxi, 114. A New Method of Studying Edema. 